\title{
西ドイツの村落再整備制度 一都市建設と農地整備の協同一
}

東

\section{I はじめに}

我が国の農村整備をもっぱら農村の居住環境整 借という意味において理解する時，西ドイツにお いてこれに対応するのは村落再整備(Dorferneuerung)である。

我が国の農村整備については, 補助事業として 農村総合整備モデル事業（それの前提としての農 村総合整備計画策定）等は存在するが, 土地利用 に関する計画制度，事業制度等を含む農村整備の 統一的な法制度は存在していない。この点は, 西 ドイッの村落再整備についても事情は同様であ る。その 1 つの大きな理由は, この種の領域が都 市計画と農業政策の 2 つ分野の交錯する場で排 他的にどちらに属するというものではないからと 考えられる。しかしながら，西ドイツにおいて は, 村落再整備の統一的な法制度は存在しないも のの, 都市建設（西ドイツにおける都市計画であ る）制度と農業側の農地整備制度との一種の協同 関係が成立しており, 実質的には農地整備事業が 村落再整備をおしすすめている。

本稿は, まず西ドイッの村落再整備とは何か明 らかにし, 次の,このような村落再整備がどのよ うな背景の中で成立したか扱う。次に, この村落 再整備という課題をあつかう計画制度と土地整備 制度がどのようなものか論述するとともに各法制 度の比較を行い, 都市建設側の制度と農業側の制 度の協同関係を明らかにする。更に,このような

* 農業総合研究所

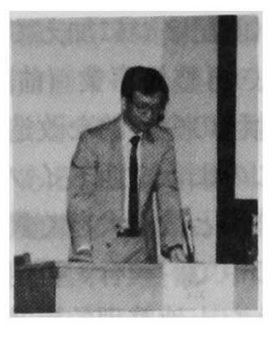

協同関係がどのような歴史的経緯で形成されたか 明らかにしたい。

\section{II 村落再整備とは何か}

村落再整備の内容としては, 通常 3 つのものが 考えられる。1つは, 農林地を新たに農外の目的 のために開発する村落開発 (Dorferweiterung ないしは Dorfentwicklung)，2つ目は農林地の 整理をおこなう固場整備 (Feldbereinigung 狭い 意味の農地整備)，3つ目は建築用地, 交通施設 用地, 公共施設用地等からなる村落居住地区の 再開発 (Dorfsanierung) である。実態としてみ れば, 最後の再開発は第一番目の村落開発なく しては不可能であり, 多くの場合第二番目の圑場 整備と一緒に行われる。したがって, 最も広くと れば以上 3 つを含めて村落再整備ということが ある。しかし, 本稿では, 圃場整備を除き, 第 一番目の村落開発と第二番目の村落再開発をあわ せたものと考える。したやって，この村落再整備 は, 農地整備事業が村落居住地区を含み一体的に 行う場合もあれば, 純粋に都市建設の中で行わ れる場合もある。

このように定義された村落再整備の理念は, 言でいえば居住環境の整備である。その具体的な 課題は, 基盤（インフラストラクチュア）整備の ための公的措置（居住地区の拡大, 街路の拡張, 排水路の整備等の公共施設整備等) と私的な措置 (住居家屋や経営家屋の私的な改善) とされる。 村落再整備をその規模ないしは複合度によって 
単一事業 (既存集落の僅かな改変), 複合事業 (村 落居住地区の外縁部の大規模な整備)，再開発事 業（前記 $2 つ に$ 加えて村落中心部の大規模な再開 発)，再整備事業（前記 3 つを同時に行う村落居 住地区の全般的な改造）に分類できる。

このような西ドイッの村落再整備が我が国の農 村整備と最も大きく異なる点は，第一に公的な措 置の中で, 複合, 再開発, 再整備事業にみられる ような土地整理的事業が行われることであり，第 二に家屋の改修や改築のようなどちらかといえば 私的な領域に属すると考えられるような事業が行 われることである。

\section{III 農業と農村の変化と}

\section{村落再整備の発生}

前章でのべたような西ドイツの村落再整備の特 色はどういう事情で生じたのだろうか。このこと を西ドイツの農業と農村の素描を通じてさぐる。

第一に，西ドイツの農業は，英仏とともに北西 ヨーロッパに支配的な三圃式による有畜畑作農業 であり，水田農業たる我が国と大きな対象をみせ る。このことから, 北西ヨーロッパの農村社会は 土地が制約資源であり，我が国は水が制約資源で あったともいわれる。

第二に, 経営単位あたりの平均経営農地面積規 模は15.8ha (1982年) であり，米，英，仏よりも ずっと小規模であるが，我が国よりはるかに大規 模である。

第三に，村落の空間的形態は，ヨーロッパでは 中小規模の戸数をもつ集居ないしは密居集落が支 配的であり，村落居住区は空間的に完結した区域 である。我が国においても集密居集落が過半数を 越えるとされる。

第四に，他の西欧諸国と同様に我が国に先立っ て工業化を中心とする経済発展を達成し，それに 伴って激しい都市化現象を体験した。ただし，西 ドイツは自然及び歴史的条件から分散的都市体系 が早くから成立し，我が国ほど大規模な地方圈か ら大都市圈への人口移動はなかった。人口移動と いう観点ではなく, 密度からみれば, 我が国は,
狭い平地部のため高い可住地人口密度をもち（高 密度の経済活動をもたらす)，同時に都市と農村 の人口密度の差が少なく（都邑連続社会の基礎を なす)，この意味で西欧諸国とは隔絶した都市化 社会である。但し，西ドイツは西欧諸国のなかで は密度の点では（オランタ，ベルギーと並んで） 相対的に我が国に近い条件を有する。

このような西ドイツの農業と農村の状況は, 我 が国とは根本的な相違を有する西欧諸国に属する とはいえ，それでも相対的には我が国に近いとい うイメージを与える。

西ドイッにおける村落再整備の発生は, 我が国 の農村整備よりもずっと古く19世紀前半に遡る。 そして第一次大戦後になるとプロイセン地方で は, 農地整備の中で村落居住地区の整備を含めて 行うことが急増した。この理由は，工業化による 離農増加と農業の機械化の進展による農業の集約 化の結果として, 農業経営用の改築が求められた ことによる。具体的には放牧式から舎飼式になり 頭数も大幅に増えたことによる家屋の大規模化と ともに，家屋と圃場の緊密化が必要とされた。こ のような意味での村落再整備においては,

1）村落居住地区から圃場へつながる農道の新設 や既存の集落道の拡張・改修

2）境界整理や農地と宅地の交換によって経済的 必要にこたえうる農場敷地の創出

3）固場と村落居住地区を周回道路によって明確 に区別するとともに農場裹の圃場へ通じる出口道 の整備による村落居住地区中心部の交通の軽減

4）これらに必要な老朽化した家屋の改築

などが行われたという。そして，村落再整備はそ の発生当初から農地整備と一体として行われてき たとされる。

第二次大戦後は, 以上のような意味でのもっぱ ら農業的な理由に基づく村落再整備に加えて，新 たな農村の変化による村落再整備が加わった。

この時期約30年間の農業構造の変化は, 一言で いえば,

1) 農業経営数 ( 1 ha以上) の半減（164万余から 76 万余) とそれによる平均経営面積の増大 (8.1 ha から15.8ha)

2）貢貸（小作率71\%）等による上層経営の增加 
(20ha以上の経営が全経営の $27 \%$, 全経営農地 の $66 \%$ をめる)

3）第 II 種兼業農家の増加（全経営数の $40 \%$ ，全 経営農地の13\%)

ということができる。

この結果，農業就業人口は15\%（1950年）から $5 \%$ （1970年）と大幅に減少し，同時に，前記の 分散的都市体系もあり，農村は，都市へ通勤者を 含む多くの非農業従事者の居住する場所へと変化 していった。この変化により，都市近郊を中心と した農村において, 新市街地開発, 公共施設建設 等のための非農用地創出を目的とする村落再整備 が増加してきた。

\section{IV 計画制度}

我が国では村落居住地区を対象にして土地利用 の方向づけや土地利用・建築規制を含むような計 画制度は存在しない。一定の要件に該当する市町 村が都市計画をもつにすぎない。他方，農振法は 農用地を対象にした農用地利用計画を有するのみ である。西ドイッの村落再整備については，この ような意味の計画制度は存在するだろうか。

第一の可能性は，連邦建設法に基づいて全ての 市町村に策定権能が存する建設管理計画(Bauleit plan) である。この建設管理計画は,土地利用計 画 (Flächennutzungsplan, F プラン) と建築詳 細計画 (Bebauungsplan, B プラン) の 2 つから 構成されている。前者は, 後者の準備的計画の性 質をもつものであり，市町村の全域を対象として 作成され，市町村の予見しうる需要を基礎とした 土地利用が概要の形で定められる。ただし，この F プランは，私人を直接拘束するのものでなく， 市町村及び他の公の計画主体をこれに適合するよ うに拘束するにとどまる。B B ランは，Fプラン に基づいて建築的利用の種別・利用率, 建築形式, 敷地の最小規模, 建造物の高さ等を私人に対して 拘束的に定めた計画である。

なお，国土は原則的に建築禁止地域であり，建 築行為が行われるためには, 市街地に連坦した区 域内かあるいは B プランの地区内にあることと，
市街地としての地区施設が十分に整備されている ことが必要である。

第二の可能性は, 農地整備庁が策定する農地整 備事業のための道路・水利計画である。この計画 は, 農地整備区域内の道路や水利施設等の共同及 び公共施設に関するものである。この計画は, 計 画決定によって一定の法的効果を有する。したが って, 部分的には村落居住地区の再整備の計画と して機能しうる。ただし、この計画は元来生産基 盤整備を狙ったものであるので, 農地整備法の中 には規定されていないが農地整備庁による農地整 備事業の内部手続として村落再整備計画 (Dorfe rneuerungsplan)が補完的に策定される場合があ る。いずれにせよ農地整備庁の策定する計画は市 町村の建設管理計画に比して部分的でかつ法的規 制力も弱く，効力上も市町村のそれより劣る（連 邦建設法第38条)。

したがって，基本的に村落再整備の計画は市町 村の都市建設にゆだねられているが，市町村が建 設管理計画を策定していない場合等にはある程度 農地整備側が土地利用の方向づけの機能を果す。

\section{$\mathrm{V}$ 土地整理制度}

我が国では都市計画制度の中に土地区画整理制 度，農業側に土地改良制度がある。ただし，前者 は市街化区域内, 後者は（補助の存するのは）農 振農用地区域内と守備範囲が定められている。後 者は非農用地を事業区域内としては含みうるが, 事業費を権利者が分担しうる制度がないので実質 上事業は農地に限定されている。

西ドイッでも同様に，都市建設側では連邦建設 法に区画整理 (Umlegung)，農業側では農地整 備 (Flurbereinigung) があるが両者の関係はやや 異なる。

区画整理は，Bプラン地区内に限り行われ市町 村が事業主体になる。

農地整備は, 制度のそもそもの目的から B プラ ン地区外が中心になるが $\mathrm{B}$ プランの実現という形 であれば， B プラン地区を含んで行うことは全く 問題がない。農地整備の計画に伴って B プランが 策定されることももちろんあり，その場合農地整 
備はこれに拘束される。いずれにせよ農地整備と 宅地開発とが一つの農地整備のなかで可能になる わけである。事業費の分担も参加人組合に非農家 も参加しうるので制度上の問題点はない。

したがって, 村落居住地区の土地整理手法とし て，区画整理と農地整備の両者を選択しうる。農 村的市町村では農地整備によることが多いようで ある。

\section{IV 各法制度の比較}

村落再整備の実施に当たってその基礎となる 3 つの法制度, すなわち, 連邦建設法, 都市建設促 進法及び農地整備法の比較を行う。

連邦建設法に基づく場合，村落再整備は基本的 に建設管理計画とりわけB プランの策定とその実 現という形になる。したがって, 内容的には都市 建設のみに限定されるとともに事業主体が市町村 でないような各種の事業を実施することができな い。区画整理事業では等価換地の原則がないので 強制的金銭清算を行うことができるが, 既に述べ たように空間的にはB B プランの区域内に限定され る。計画の面では, 建設管理計画のもつ官庁や土 地所有者への法的拘束力の強さや, 収用等の都市 建設上の各種の手法の利用が可能であること大き な長所であるが, 他方, 計画の策定, 変更等に相 応の手続が必要となる。更に, 連邦建設法に属す る村落再整備プログラムは特に存在しないので, この意味では村落再整備の促進力を持たない。加 えて, 農村的市町村にとっては建設管理計画の策 定が能力的に困難な点もある。

都市建設促進法に基ずく場合, 通常の連邦建設 法の制度よりも更に権利制限的な計画利得の吸収 等の各種の制度手法を用いることができるが, 先 にも述べたような農村的市町村の能力からすれば 有効性に比して費用が大きなものになる。また，

同法に基づく都市再開発及び都市新開発措置に対 する連邦の補助プログラムが存するが, 農村地域 には配分が僅かであるとされている。

農地整備法に基づく場合，農地の交換分合の一 環として, 村落居住地区が事業区域に含められて
行われる。既に述べたように，村落居住地区にお ける土地整理を誘導するものとして連邦建設法の 建設管理計画の策定が行われる。したがって，村 落再整備を担当するに当たって空間的な限界は存 しない。制約としては, 農地整備による居住地区 の土地整理は, 制度上農地整備の目的に適合する ものでなければならないという要件がある。但 し，次章に述べるように事実上この制約は弱い。 むしろ, 現在農地整備の手法的な制約として指摘 されているのは，等価換地の原則が保持されてい るので実効性を失う可能性が少なくないことであ る。

\section{VII 制度確立の歴史的経緯}

以上述べた村落再整備のための制度の形成に当 っては，都市建設法制と農業（農地整備）法制の 間の緊張関係等いくつかの点で法的に解決されな ければならない以下のような問題があった。

\section{1 農地整備開始手続}

村落居住地区を農地整備事業のなかに含める場 合, 歴史的には農地とやや違った手続がとられて いた。すなわち, 農地整備の初期 (19世紀) 各ラ ントの法律は, 農地整備の導入手続として関係者 の一定比率の同意を要求するが, 他方では市街 地, 庭園, ブドウ畑等を含めるためには所有者の 全員同意を要求している。これが，プロイセンの 耕地整理令（1870年）において所有権者の過半数 の同意があれば可能になり，更に，ナチス・ドイ ツの帝国整理令（1937年）に至って同意は不要と された。さいごの時期は, 事業導入そのものにつ いての職権主義が確立された時期でもある。初期 の全員同意という厳しい要件を緩めていくことが 村落再整備の必要性に応えていくための条件であ ったと考えられる。

\section{2 都市建設との調整}

1953年の旧農地整備法第37条第 3 項に, 各種の 計画によって農地整備が村落居住地区を対象とす ることを妨げられない旨の文言が規定された。こ 
れは, プロシア建築線法, 住宅法等を基礎として 確立しつつあった都市建設の計画法制との摩擦が 生じていたことを背景にしている。ただ,この規 定では, 農地整㣁は土地整理手法として排除され ないとしても，計画制度としてどちらが優先する かかならずしも明らかではなかった。

これが1960年の連邦建設法の制定によって，市 町村の都市建設領域での計画高権が明定されると ともに，建設管理計画の計画上効力の優位性が規 定された（連邦建設法第38条）。

同法によって計画は都市建設で土地整理は選択 的という現在の基本的仕組が確立したのである が，これによって都市建設と農地整備が協同して 村落再整備を行うには，協同方式を具体的に定め る必要があった。1971年の都市建設促進法改正, 1976年の連邦建設法と農地整備法の同時改正によ ク,これについて詳細に定められた。

\section{3 農地整備の目的}

農地整備事業が村落居住地区を含めることにつ いては，農業生産基盤の整備という制度目的の逸 脱ということで問題にされることが多かった。現 在農業的な土地利用がされている地域の市街地開 発，また，既に市街地である地域の再開発とい う 2 つの場合が考えられるが, 農地整備の目的 (Landeskultur，一般的農村基盤整備）からの 逸脱, あるいは, 対象要件としての「農村的土地 保有」からの逸脱という形で，しばしば，農地整 備事業に含められることに不満をもつ土地権利者 によって争われた。

判例の発展は「相当の都市的要素を取りこんで も農地整備手続が違法でないという風に判断して きた」とされる。そして，最終的には1976年の農 地整備法の改正により，第一条の目的の中に，農 村開発 (Landentwicklung) が新たに付け加わり， 非農用地需要を含む「土地に対する種々の利害と 要求の調整」を行う法的基盤が与えられた。

\section{4 村落再整備措置}

また，1976年の農地整備法改正では，第37条で 従来「居住地区の密度緩和 (Auflockerung der Ortslage)」を行うことができるとあったのが,
「村落再整備のための措置を伴せて実行すること ができる」と改められ，農地整備の目的の範囲内 で, 都市建設的な土地整理の目的の範囲内で, 都 市建設的な土地整理のほか, 同様な道路建設, 地 区基盤整備，家屋改築等を農地整備事業として実 施することに明確な法的基礎があたえられた。

\section{VIII むすび}

本稿を要約すれば以下のとうりである。

1）西ドイッの村落再整備は, 家屋の改築・改修 や市街地の開発・再開発・を含む点で我が国の農 村整備と大いにその内容が異なる。

2)このような村落居住地区を対象にした村落再 整備は，既に19世紀から農地整備の中で行われて きたが，第一次大戦後プロイセン地方を中心とし て, 農業（農法）の変化（集的化，多頭化）を原 因として盛んになり，第二次大戦後は都市化の進 展（非農用地需要）も加わって更に推進された。 3）村落再整備の計画制度としては，都市建設側 の連邦建設法による市町村策定の建設管理計画に 基本的にゆだねられている。土地整理制度として は，都市建設側の土地区画整理と農業側の農地整 備を選択しうるが, 農地の整備と市街地開発とを 一体的に行える農地整備によって行う方が利点が 多い。事実, 農村的市町村では農地整備によるこ とが多いという。この意味で, 計画は都市建設, 土地整理（基盤整備を含む）は農地整備という分 担を基礎にした協同によって村落再整備が行われ ている。

4）農地整備が村落居住地区を含んで土地整理を 行うことは古くから行われてきたが, 制度的にこ れを確立するにはいくつかの点で法制上の努力を 要した。

以上の西ドイツの村落再整備の検討から, 今後 の我が国の農地整備について問題提起を行うとす れば次のようになる。

1）我が国で西ドイッで行われているような内容 の村落再整備は必要ないのだろうか。ないとすれ ばなぜか。あるとすればなぜ行われないのか。

2）我が国の都市計画制度が農村に適しないとい 
う問題があるとしても，西ドイッ型の計画は都市 計画側で土地整理は農村整備側という方式は, 我 が国の将来の制度の1つの可能性として考えられ ないか。

3）我が国の土地改良制度を，西ドイツの農地整 備制度の発展にならって農地整備（村落再整備） の土地整理手法として発展させていくことはでき ないのか。
注

1）本稿は、東 廉「都市化地域の土地利用調整に おける農地整備制度」(「農業総合研究」第38巻 第 3 号、1984年）を村落再整備について発展さ せたものである。

2）村落再整備をの類型については、東 廉「西ド イッにおける農地地域の中心集落」(「農村中心 集落実態と計画課題」農村生活総合研究セン夕 -1985 年 3 月）参照。

3）村落再整備の歷史については、Osthoff, f, F. Flurbereinigund und Dorferneuerung, Sch riftenreihe fur Flurbereinigung, Heft 42、1967による。

4）「世界の農地・農村整備一農地・農村整備手法 に関する比較研究」農政調査委員会、1983年の 田山輝明論文参照。 


\section{British Rual Planning: Movement from Planning to Management by Yoshihiko Oyama (The Rural Life Research Institute)}

In Britain, where urbanization has penetrated deep into the countryside and where the agricultural work force has become less than $3 \%$ of the total, how to plan and manage rural areas is of deep concern to the whole nation. This article follows the chronological change in rural planning issues and how statutory planning has responded. With this background, current issues in highly urbanized countryside are examined by focusing on three areas: environmental deterioration and land use conflict in the urban fringe, conflict between modern farming and conservation, and the deprivation of remoter rural communities. It has become increasingly clear that the traditional statutory 'planning' approach cannot cope with them properly, and the author looks into the underlying reasons. This is followed by reference to a new 'management' approach and its practical outcome, known as 'Groundwork', which introduces an idea of partnership with the charitable and professional Groundwork Trust acting as a new change agent. It is regarded as an unconventional approach initiated in the contemporary conditions and possibilities.

\section{Village Renewal in the F.R. of Germany: \\ A Co-operation of Urban Construction and Rural Land Consolidation \\ by Ren Azuma (Japanese National Research Institute of Agriculural Economics)}

This paper focuses its attention on the historical development and status quo of the legal framework of village renewal in the F.R. of Germany.

The village renewal in the F.R. of Germany contrasts with that in Japan, in that the former includes the development or renewal of built-up areas and the removal or large-scale improvement of houses.

This village renewal has been conducted as part of rural land consolidation projects since the early 19 th century. After World War I especially in Preussen, it was put into common practice due to the development of large-scale and intensive cattle farming which demanded modernization of facilities. After World War II urbanization and growing demand for urban land uses in rural areas made it more popular.

Two legal bases are necessary for implementing the village renewal projects; the first one makes it possible to establish a plan to control land-use and housing, and the other gives the authority power to reoder land and realize the plan. The two bases are delivered by the Bundesbaugesetz (Urban Construction Act) on the urban planning side and the Flurbereinigungsgesetz (Land Consolidation Act) on the rural planning side. In this way the two planning sides share the task and co-operate with each other legally. Actually in many cases the rural land consolidation authority carries out the task, because the combination with rural land consolidation gives many advantages and subsidiary programs are available only on the rural planning side.

It is not self-evident that the rural land consolidation projects can include the built-up area of a village and implement village renewal measures. Historically we can trace back the efforts on the rural planning side to firm its legal base for village renewal. 